\title{
An Empirical Analysis of Stock Market Performance and Economic Growth: Evidence from India
}

\author{
Sudharshan Reddy Paramati \\ Research Analyst, National Institute of Financial Management (NIFM) \\ Ministry of Finance, Government of India, Sector 48 \\ Faridabad, Haryana, India-121001 \\ E-mail: psreddyhcu@gmail.com \\ Rakesh Gupta \\ Faculty at Department of Accounting, Finance and Economics \\ Griffith Business School, Griffith University, Australia \\ E-mail: r.gupta@griffith.edu.au
}

\begin{abstract}
This study aims to investigate whether the stock market performance leads to economic growth or vice versa; study also examines short-run and long-run dynamics of the stock market. We use of monthly Index of Industrial Production (IIP) and quarterly Gross Domestic Production (GDP) data for the time span of April, 1996 to March, 2009. This provides rich data for the empirical analysis. We undertake; Unit root (ADF, PP and KPSS) tests, Granger Causality test, Engle-Granger Cointegration test and Error Correction Model. The monthly results of Granger causality test suggest that there is a bidirectional relationship between IIP and Stock prices (BSE and NSE) and quarterly results reveal that there is no relationship between GDP and BSE but in the case of NSE and GDP there is a unidirectional relationship and that runs from GDP to NSE. The Engle-Granger residual based cointegration test suggests that there is a long-run relationship between the stock market performance and economic growth. Similarly, the results of error correction model reveal that when the long-run equilibrium deviates then the economic growth adjusts to restore equilibrium by rectifying the disequilibrium. This study provides evidence in favor of 'demand following' hypothesis in the short-run. Main contribution of the study is in identifying the role of economic growth in stock market development.
\end{abstract}

Keywords: Stock market performance, economic growth, causality test, short-run and long-run dynamics

\section{Introduction}

The relationship between financial sector development and real economic activity has been a debatable issue in theoretical and empirical research. Schumpeter (1911) argues that well functioning financial systems encourages technical innovations by reallocating resources to the entrepreneurs and promote economic growth. The stock market performance and economic growth has been the subject of intensive theoretical and empirical work. This debate revolves around whether stock price movements are influenced by economic changes or stock market performance helps in promoting economic growth. In this regard questions under consideration are; is there a relationship between financial sector 
development on economic growth and the identification of causal nexus between economic growth and financial development (Deb and Mukherjee, 2008).

The main objective of this study is to investigate the causal nexus between stock market performance and economic growth and to find the short-run and long-run dynamics of the variables by considering both monthly and quarterly data on Index of Industrial Production (IIP), Gross Domestic Production (GDP) and Stock Prices in the Indian context. Understanding of this relationship is important for policymakers to assist with development of policies for future economic development and direct allocation of resources in an optimal fashion. This is also of interest for investors in terms of understanding future movement of the stock prices in the market place. To our understanding this relationship has not been tested in the context of Indian market as yet. This study is the first study testing this relationship comprehensibly.

Causal nexus between economic growth and financial development has been of considerable attention in terms of identifying the causal direction. There is significant development in stock market of India after introduction of 'New Economic Policy (1991)' in India and debate commenced on the role of stock market performance promotes economic growth or vice versa; one stream of research suggests stock market development promotes economic growth. Opposite view is held by some researchers who have argued that this effect is marginal or in some extreme cases even negative. There are number of studies that have tested direction of causation between financial development and economic performance both at developed and developing countries. However, there are few studies which are addressing the vibrant causal relationship among stock market development and economic performance (Levine and Zervos 1996; Jefferis and Okeahalam, 2000; Shirai, 2004; Adajaski and Biekpe, 2006; Mun et al., 2008). Some studies documented that stock market development has played an important role in promoting economic growth in some economies; e.g., Demirguc-Kunt and Levine (1996); Levine and Zervos (1998). The empirical evidence from the literature suggests that the direction of causality between stock market development and economic growth has been inconclusive (Odhiambo, 2008) and it indicates that results are sensitive to the model employed and type of data used in the analysis. Outcome also differs from country to country over the time period.

India has adopted modern strategies to promote its stock market development since late 1980s and this has become more sophisticated after the introduction of economic reforms of 1991. These reforms brought expansion in terms of number of listed companies, number of shareholders in the market and market capitalization; this has resulted in India to become one of the most active and leading market among all developing countries of the world (Nagaishi, 1999). Economists often say that the movements of stock prices either 'up or down' are reflective of public expectations towards policies. An increase in stock prices is reflective of future expansion of economic growth and a decline in stock prices is associated with expected potential economic recession (Mun et al., 2008). The ongoing debate was initially concentrated on financial development and economic growth. Since last few decades the growing importance of stock markets in developing countries in promoting economic development process has continued to attract attention in both academia and among policy-makers. With these developments, stock markets have been playing an important role in mobilizing domestic savings by providing suitable incentives to savers to diversify their portfolios (Vazakidis and Adamopoulos, 2009). Stock markets offer capital investment at competitive cost to entrepreneurs that boost the economic development.

The remainder of this study is organized as follows: Section 2 provides a brief theoretical and empirical review of literature on the causality between financial development and economic growth and the stock market development and economic growth. Section 3 discusses nature and sources of data, variables and empirical methodology for testing causality and identification of short run \& long run relationship among the variables. Section 4 presents empirical results of the study. Finally, section 5 provides summary and conclusion of the study. 


\section{Literature Review}

This study has conducted a comprehensive literature survey on both developed and emerging economies; to review, a broader theoretical and empirical literature on financial/stock market development and economic growth. Understanding of this relationship from the standpoint of developed markets and historical perspective will assist with developing this intuition for India for empirical analysis.

\subsection{Financial Development and Economic Growth}

The relationship between financial development and economic growth has been extensively studied in last few decades. The issue is not new in economic literature and it has evolved from the idea provided by Schumpeter in 1911. Schumpeter has discussed the importance of financial sector development in promoting economic growth in his seminal work. His study pointed out that a well functioning financial system advances technological innovations by providing sufficient funds to the entrepreneurs that eventually turn to enhance economic growth. This relationship between financial sector development and economic growth has been discussed by Debreu (1959), Arrow (1964) and Patrick (1966). It was empirically tested by Goldsmith (1969) in his work by using the cross country data, where he indicated the relationship between financial development and growth. The role of financial sector development under the 'demand following' and 'supply leading' approach was studied by Patrick (1966). In the 'supply leading' role, the causality occurs from financial development to economic growth and in case of 'demand following' role it is from economic growth to financial development.

It is often asked why these studies are important in economic literature. For the policymakers standpoint it is important to know what direction causality exists between financial sector development and economic growth; for example if causality occurs from financial sector development to economic growth then it has direct policy implications. As it is evident from the existing literature that a more efficient financial system will always enable an economy to enhance its real GDP growth. Given this, policymakers will make the policies towards minimizing market failures by stipulating the services that makes easy transactions, mobilize capital and exert corporate governance, in doing so that ultimately advances economic growth (Sinha and Macri, 2001).

The financial system plays an important role in full-filling the needs of investors by mobilizing funds and transforming them into an asset (Ndikumana, 2001). In such a way that, an efficient financial system allocates the resources efficiently through its financial intermediaries, which eventually identify the most productive investment opportunities. Abu-Bader and Abu-Qarn (2005) study documented that the direction of causality runs from financial development to economic growth in Egypt, either through increasing investment efficiency or through increasing resources for investment. Deeper, broader, and better functioning of the financial system can stimulate higher economic growth (King and Levine 1993a \& 1993b). However, earlier studies in developed economies (Robinson, 1952; Kuznets, 1955; Friedman and Schwartz, 1963) provided evidence in support of economic growth lead to financial sector development. Other empirical studies by Demetriades and Hussein (1996); Luintel and Khan (1999), Arestis et al. (2001) show that causality runs in both the directions i.e., financial development causes economic growth and vice versa. Goldsmith's (1969) study provides evidence that there is a positive connection between financial development and economic growth. On the contrary, Ram (1999) study did not find any relationship between financial development and economic growth in his analysis of cross country data.

\subsection{Causal Direction of Economic Growth and Stock Market Developments}

The importance of stock markets in both developed and developing economies of the world has shifted the research focus to identify the cause and effect relationship between stock market development and economic growth over the last few decades. Since late 1980s there has been significant development in emerging stock markets particularly; in terms of market capitalization, listed companies and 
shareholders. El-Wassal (2005) notes that the emerging stock markets capitalization has increased 32 times and developed stock market's capitalization has increased only 11 times between 1980 and 2000. This shows the expansion of emerging stock markets capitalization is almost three times larger than expansion of developed stock market's capitalization. It is often debated that if stock market can predict the economy growth or vice versa. Economists (e.g., Jefferis and Okeahalam, 2000; Shirai, 2004; Adajaski and Biekpe, 2006; Mun et al., 2008) believe that larger increase in stock prices is reflective of future economic growth, and large decrease in stock prices is an indication of future economic recession.

Levine and Zervos (1996) examined whether there is a strong empirical connection between stock market development and long run growth for forty-one countries by using data from 1976 to 1993 on real per capita average growth and stock index. Results of cross-country growth regression suggest that a pre condition of stock market development is positively and strongly associated with long-run economic growth. Mun et al. (2008) tested the causal relationship between stock market and economic activity in Malaysia for the period of 1977 to 2006. Their study used annual data on real GDP and Kuala Lumpur Composite index (KLCI), results from Granger causality test indicated that causality runs from stock market to economic activity and not the other way around. Pearce (1983) study showed that stock prices could lead the direction of the economy. His study was carried out for the time span of 1956 to 1983 for the U.S. and discovered that stock market is as an indicator of economic growth.

Empirical studies of Atje and Jovanovich (1993); DemirgüçüçKunt and Levine (1996); Korajczyk (1996); Levine and Zervos (1996 \& 1998) showed that there exists a strong positive relationship between stock market development and economic growth. Alam and Hasan (2003) find that the stock market development has a sizeable positive impact on economic growth in the case of US. In a similar study by Agarwal (2001) investigated the relationship between stock market development and economic growth for nine African countries with cross sectioned data for the period of 1992 to 1997 . His study documents a positive relationship between several indicators of the stock market performance and economic growth. Atje and Jovanovic (1993), Caporale et al. (2004), Adajaski and Biekpe (2006) also show that financial intermediaries usually have less information as compared to stock markets and these markets efficiently allocate the resources and enhance economic growth. Likewise, Filer et al. (1999) find that an active equity market plays an important role in promoting economic growth in developing countries.

Dailami and Aktin (1990) find that a well developed stock market can enhance savings and provide investment capital at lower costs by offering financial instruments to savers to diversify their portfolios. In doing so, these markets efficiently allocate capital resources to productive investments, which would eventually promote economic growth. The causal nexus between stock market development and economic growth was examined by Vazakidis and Adamopoulos (2009) for France for the period of 1965 to 2007. This study employed co-integration, Granger causality test and Vector error correction model; results indicate that there is a positive association from economic growth to stock market development and at the same time interest rate has a negative effect on stock market development. Similarly Brasoveanu et al. (2008) have studied the correlation between capital market development and economic growth in Romania for the period 2000 to 2006. Results indicate that capital market development is positively correlated with economic growth by way of feed-back effect. However, the strongest link is from economic growth to capital market, signifying that financial development follows economic growth. Likewise, El-Wassal (2005) study also supports demandfollowing hypothesis in 40 emerging economies, where emerging stock markets development is determined by economic growth, financial liberalization policies and foreign portfolio investment.

Arestis et al. (2001) have investigated the relationship between stock market development and economic growth, controlling the effects of banking system and stock market volatility by utilizing time varying quarterly data from five developed economies (France, Germany, Japan, United Kingdom and United States) for the time span of 1968 to 1998. Results addresses that both stock markets and banks seems to play an important role in promotion of output growth in France, Germany and Japan 
but in case of United Kingdom and United States the link between financial development and growth found to be statistically weak. Study concluded that bank-based financial systems may able to promote long-term growth than capital market based ones. Oskooe (2010) also systematically investigated the relationship between stock market performance and economic growth in Iran by using real GDP and stock price indices for the period of 1997 to 2008. Results of the study indicated that stock price movements are influenced by the level of real economic activity in the long-run and in the short-run stock market plays an important role as a leading economic indicator of future economic growth in Iran.

There are some other studies addressing about diversification of risk and economic growth, for instance; Pagano, (1993) study stated that a sound performing and liquid stock market that ultimately allows investors to diversify away unsystematic risk, which eventually turn to encourage the marginal productivity of capital. Obstfeld (1994) has pointed out that international risk sharing by way of internationally integrated stock markets can advance the allocation of resources and accelerates the process of economic development. In the same way, Korajczyk (1996) study finds that internationally integrated stock markets tend to amplify capital accumulation and have positive association between stock markets integration and economic growth. Gupta and Donleavy (2009) also investigated the benefits of diversifying investments into emerging markets. Results show that despite increasing correlations, there are still potential benefits for Australian investors who diversify their investments into emerging markets. Contrary, studies of Shleifer and Summers (1988); Morck et al., (1990a) showed that stock market development would lead to harm the economic growth by easing counterproductive corporate takeovers. In a similar fashion, Devereux and Smith (1994) study also specified that greater risk sharing through internationally integrated stock markets can minimize saving rates and that would decelerate the economic growth. Some other empirical studies (Bencivenga and Smith, 1991; Naceur and Ghazouani, 2007; Adajaski and Biekpe, 2006) who could not determine any significant relationship between stock market development and economic growth, particularly in developing countries. Likewise, Barro, (1989) study also found evidence that stock market development doesn't support as a leading indicator of economy.

\subsection{Studies of Relationship in Indian Context}

The existing studies on the connection between financial/stock market development and economic growth in Indian context are as follows. Sinha and Macri (2001) study presents that there is a positive and statistically significant relationship between the income and financial variables for India, Malaysia, Pakistan and Srilanka. Results of the study can not be generalized. Kamat and Kamat (2007) have investigated the nexus between developments in financial intermediation and economic growth for India for the period of 1971 to 2004. Their results support 'supply leading hypothesis' for India i.e., financial sector development leads to stimulate economic growth in the short-run. Similarly, Bhattacharya and Sivasubramanian (2003) study finds that financial sector development leads to promote GDP and not the other way. Acharya et al. (2009) investigated the nexus between financial development and economic growth in Indian states for the time span of 1981 to 2002. Results indicate that there is a long-run relationship between financial development and growth across Indian states. This study concludes that economic growth is followed by financial development.

Padhan (2007) examined the causal linkages between stock market and economic activity in India for the post liberalization period by using monthly data on IIP and stock prices of Sensex for the time period of 1991 to 2005. Empirical results from TYDL model (Toda-Yamamota, Dolado and Lutkephol model) exposes that there is a bidirectional relationship between stock prices and economic activity and it implies that a well developed stock market will stimulate economic activity and vice versa. In a similar study by Agrawalla and Tuteja (2007) found that stable long-run equilibrium relationship exists between stock market development and economic growth in case of India. Deb and Mukherjee (2008) tested the causal nexus between stock market development and economic growth for Indian economy for the period of 1996 to 2007 by using quarterly data on real GDP, real market capitalization ratio and stock market volatility. Their study finds strong causal flow from the stock 
market development to economic growth and also evidenced that there is a bi-directional relationship between market capitalization and economic growth; finally their study concludes that 'supply leading' hypotheses exists in Indian context. However, Chakraborthy (2008) study indicates that causality runs from the GDP growth to stock market growth.

Based on the review of published literature we find current evidence on nexus between economic activity and financial development is conflicting. Our study aims to test this relationship using most recent data and advanced econometric techniques in the context of India. Understanding of this relationship will provide important insight into this relationship for policy makers who seek to develop economic policies to best target for a sustainable economic development. This will be of importance for investors who are interested in the future direction of economic development and stock market movements. India provides a unique opportunity for this analysis because of its rapid economic activity in the recent past and also because of well established stock markets. Mumbai (previously Bombay) stock exchange is one of the oldest existing stock markets in the world.

\section{Data and Methodology}

The present study uses monthly and quarterly data for the time span of April, 1996 to March, 2009. The collected data are seasonally adjusted to correct seasonal variations and then converted into natural logarithms (ln) for all the variables. The required data on Index of Industrial Production (IIP) and Real Gross Domestic Production (RGDP) are collected from RBI (Reserve Bank of India)'s publication of 'Handbook of Statistics on Indian Economy, 2009-10. Data on indices of BSE-SENSEX and NSES\&P CNX Nifty are collected from BSE (Bombay Stock Exchange) and NSE (National Stock Exchange) official websites.

\section{Variables:}

For monthly analysis - IIP (Index of Industrial Production is used as a proxy for GDP), BSESENSEX and NSE-S\&P CNX Nifty (Broad based active indices of stock markets of India). For quarterly analysis - RGDP (constant prices with base year 1999-2000), BSE-SENSEX and NSE-S\&P CNX Nifty (quarterly average closing prices) are used for the analysis.

\section{Empirical Model:}

The present study undertakes a comprehensive set of econometric tests for the empirical analysis such as; Unit root (ADF, PP and KPSS) tests, Granger Causality test, Engle-Granger Cointegration method and finally; Error Correction Model (ECM). These models are described as follows:

\subsection{Unit Root Tests}

The study starts with the conventional unit root tests, to find out the order of integration by using the Augmented Dickey-Fuller (Dickey and Fuller, 1979) test, Phillips-Perron (Phillips and Perron, 1988) test and the KPSS (Kwiatkowski et al. 1992) test. All of these unit root tests are used to test whether the data contains unit root (non-stationary) or is a stationary process. A series is said to be stationary if the mean and auto co variances of the series do not depend on the time factor. Any series that is not stationary then it is said to be non-stationary. A series is said to be integrated of order ' $\mathrm{d}$ ' which can be denoted by I (d), means that it has to be differenced ' $d$ ' times before it becomes stationary. Otherwise, if a series by itself, let say stationary at levels, without having to be differenced, then that is said to be I (0). It is very essential to apply unit root tests for individual series to come up with some idea that whether the variables are integrated with same order or not, if the order of integration is same for the entire variables then it is quite possible that study can find out the long run and short run dynamic behavior of the variables by employing Engle-Granger cointegration test and error correction model. Hence, if the order of integration is not same for all the variables then it's not possible to use above methodology (cointegration and error correction model) for the analysis. In case of both ADF and PP 
tests, the null hypothesis of non-stationary (unit root) is tested against the alternative hypothesis of stationarity.

For the Augmented Dickey-Fuller (ADF) test; consider a simple AR (1) process:

$$
y_{t}=\rho y_{t-1}+x_{t}^{\prime} \delta+\varepsilon_{t}
$$

Where $y_{t}$ is the observed variable and $x_{t}$ are optional exogenous regressors which may consist of constant or a constant and trend, $\rho$ and $\delta$ are parameters to be estimated, and the $\varepsilon_{t}$ are assumed to be white noise (i.e., zero mean and constant variance). If $|\rho| \geq 1, y$ is a non-stationary series and the variance of $y$ increases with time and approaches infinity, on the other hand if $|\rho|<1$, then $y$ is a (trend) stationary series. Now, subtracting equation (1) both sides with $y_{t-1}$, then we get:

$$
\Delta y_{t}=\alpha y_{t-1}+x_{t}^{\prime} \delta+\varepsilon_{t}
$$

Where $\alpha=\rho-1$. The null and alternative hypotheses can be written as;

$$
\begin{aligned}
& H_{0}: \alpha=0\left(\mathrm{Y}_{t} \text { is unit root }\right) \\
& H_{1}: \alpha<0\left(\mathrm{Y}_{t} \text { is stationary }\right)
\end{aligned}
$$

and can be evaluated using the conventional $t$-ratio for $\alpha$ :

$$
t_{\alpha}=\hat{\alpha} /(\operatorname{se}(\hat{\alpha}))
$$

Where: $\hat{\alpha}$ is the estimate of $\alpha$, and se $(\hat{\alpha})$ is the coefficient standard error. The equation (2) is valid only if the series is an AR (1) process, otherwise let say, if the series is correlated at higher order lags, then the assumption of white noise $\left(\varepsilon_{t}\right)$ disturbances and is violated. Thus, the ADF test constructs a parametric correction for higher-order correlation by assuming that the $y$ series follows an AR $(p)$ process and adding $p$ lagged difference terms of the dependent variable $y$ to the righthand side of the test regression, such as;

$$
\Delta y_{t}=\alpha y_{t-1}+x_{t}^{\prime} \delta+\beta_{1} \Delta y_{t-1}+\ldots \ldots \ldots+\beta_{p} \Delta y_{t-p}+v_{t}
$$

This augmented specification is then used to test the above null hypothesis by using the $t$-ratio (1.3). Therefore, study uses MacKinnon (MacKinnon, 1996) critical values for ADF test and then it has been evidenced that ADF tests are sensitive to the selection of lag lengths. Thus, study determines appropriate lag length by utilizing Schwarz information criteria (SIC).

The Phillips-Perron (1988) test incorporates an alternative (non-parametric) method for controlling serial correlation when testing for a unit root by estimating the non- augmented DickeyFuller test equation (1.2) and it is modifying the $t$-ratio of the $\alpha$ coefficient so that serial correlation does not affect the asymptotic distribution of the test statistic. The PP test follows following statistic:

$$
\tilde{t}_{\alpha}=t_{\alpha}\left(\frac{\gamma_{0}}{f_{0}}\right)^{1 / 2}-\frac{T\left(f_{0}-\gamma_{0}\right)(\operatorname{se}(\alpha \hat{)}))}{2 f_{0}{ }^{1 / 2} s}
$$

Where $\hat{\alpha}$ is the estimate, and $t_{\alpha}$ is the $t$-ratio of $\alpha$, se $(\hat{\alpha})$ is coefficient standard error, and $s$ is the standard error of the test regression and then $\gamma_{0}$ is a consistent estimate of the error variance in equation ((1.2), it calculates as $(T-k) s^{2} / T$, where $k$ is the number of regressors, then $f_{0}$ is an estimator of the residual spectrum at zero frequency. The modified $t$-ratio is the same as that of ADF test for the asymptotic distribution of the PP test. Study uses Mackinnon (1996) lower-tail critical and $p$-values for this test.

The KPSS (Kwiatkowski et al. 1992) test differs from above unit root tests in that the series $y_{t}$ is assumed to be (trend) stationary under the null hypothesis. The KPSS test is based on the residuals from the OLS regression of $y_{t}$ on the exogenous variables $x_{t}$ : 


$$
y_{t}=x_{t}^{\prime} \delta+u_{t}
$$

The LM statistic can be defined as;

$$
L M=\sum_{t} S(t)^{2} /\left(T^{2} f_{0}\right)
$$

Where $f_{0}$ is an estimator of the residual spectrum at zero frequency and where $s(t)$ is a cumulative residual function:

$$
S(t)=\sum_{r=1}^{t} \hat{u}_{r}
$$

It is based on the residual of $\hat{u}_{t}=y_{t}-x_{t}^{\prime} \hat{\delta}(0)$. The critical values for the LM test are based on the Kwiatkowski et al. (1992, table: 1)

\subsection{Granger Causality Test}

According to the Granger (1969) causality procedure is explained as follows; the question of whether $y$ causes $x$ is to see how much of the current value of $x$ can be explained by past values of $x$ and test whether adding lagged values of $y$ can improve these estimates. It is inferred that $x$ is Granger caused by $y$, if $x$ can be predicted from past values of $x$ and $y$ than from past values of $x$ alone. For a simple bivariate model, one can test the following equation:

$$
\begin{aligned}
& x_{t}=\alpha_{0}+\sum_{i=1}^{n} \alpha_{i} y_{t-i}+\sum_{j=1}^{m} \beta_{j} x_{t-j}++u_{t} \\
& y_{t}=\alpha_{0}+\sum_{i=1}^{n} \beta_{i} x_{t-i}+\sum_{j=1}^{m} \alpha_{j} y_{t-j}+\varepsilon_{t}
\end{aligned}
$$

Where; the null hypothesis is that $y$ does not Granger causes $x$ in the first regression equation and $x$ does not Granger causes $y$ in the second regression equation.

\subsection{Engle - Granger Cointegration Test}

Engle-Granger (1987) cointegration approach explains the long-run relationship between two variables. The first step in the analysis is to determine the order of integration of each series. The second step is to identify cointegration equation using OLS method. In third step, residuals from OLS regression are tested for stationarity at levels. The present study has conducted three unit root tests such as; ADF, PP and KPSS tests to check whether the considered variables are stationary or not. The study has revealed that the observed variables contain a unit root and are integrated of order one. In the next step, we need to estimate Engle-Granger cointegration equation. The following cointegration regression model is estimated.

$$
y_{t}=\beta_{0}+\beta_{1} x_{t}+z_{t}
$$

In the next step, we need to apply ADF test on the residuals $\left(Z_{t}\right)$ to check whether the residuals are

$$
\text { stationary or not. The following equation need to be estimated. }
$$

$$
\Delta z_{t}=\beta z_{t-1}+v_{t}
$$

If the ADF test on residuals rejects the null hypothesis of non stationarity, then we can draw the inferences that the stock market performance and economic growth are cointegrated and hence they are interrelated with each other in the long run.

\subsection{Error Correction Model (ECM)}

According to the ECM approach, when two variables, for example $Y_{t}$ and $X_{t}$ are cointegrated, there must also be an error correction model that describes the short run dynamics or adjustments of the 
cointegrated variables towards their long run equilibrium. EC model consists of last period error as well as lagged values of first differences of each variable. Let us consider, the ECM specification, which can be written as follows:

$$
\begin{aligned}
& \Delta y_{t}=\alpha_{1} \Delta y_{t-1}+\alpha_{2} \Delta x_{t}+\phi z_{t-1}+\varepsilon_{t} \\
& \Delta x_{t}=\beta_{1} \Delta x_{t-1}+\beta_{2} \Delta y_{t}+\theta z_{t-1}+v_{t}
\end{aligned}
$$

Where, $\mathrm{Z}_{\mathrm{t}-1}$ is an equilibrium error. An important advantage in the ECM is that all the considered variables are stationary and standard OLS is therefore valid. This also includes both the long run and short run information. Where $\alpha_{2}$ and $\beta_{2}$ are the impact multiplier (the short run effect) that measures the immediate impact that a change in $X_{t}\left(\right.$ or $\left.Y_{t}\right)$ will have on a change in $Y_{t}\left(\right.$ or $\left.X_{t}\right)$. On the other hand, $\phi$ (or $\theta$ ) provides us with information about the speed of adjustment in cases of disequilibrium (long run).

\section{Results}

All the econometric models are estimated in Eviews version 6. The empirical inferences are drawn based on the ADF, PP and KPSS tests, Granger Causality test, Engle-Granger Cointegration test and Error Correction Model (ECM).

\subsection{Unit Root tests Results}

\begin{tabular}{|c|c|c|c|c|c|c|c|c|}
\hline \multirow[b]{3}{*}{ Variables } & \multicolumn{4}{|c|}{ ADF } & \multicolumn{4}{|c|}{ PP } \\
\hline & \multicolumn{2}{|c|}{ Level } & \multicolumn{2}{|c|}{$1^{\text {st }}$ Difference } & \multicolumn{2}{|c|}{ Level } & \multicolumn{2}{|c|}{$1^{\text {st }}$ Difference } \\
\hline & $\begin{array}{c}\text { Constant \& } \\
\text { no Trend }\end{array}$ & $\begin{array}{l}\text { Constant } \\
\text { \& Trend }\end{array}$ & $\begin{array}{c}\text { Constant } \\
\text { \& no } \\
\text { Trend }\end{array}$ & $\begin{array}{l}\text { Constant } \\
\text { \& Trend }\end{array}$ & $\begin{array}{c}\text { Constant } \\
\text { \& no } \\
\text { Trend }\end{array}$ & $\begin{array}{l}\text { Constant } \\
\text { \& Trend }\end{array}$ & $\begin{array}{c}\text { Constant } \\
\text { \& no } \\
\text { Trend }\end{array}$ & $\begin{array}{l}\text { Constant } \\
\text { \& Trend }\end{array}$ \\
\hline BSE & $-0.62(0.86)$ & $\begin{array}{l}-1.60 \\
(0.78)\end{array}$ & $\begin{array}{l}-12.63 \\
(0.00)^{*}\end{array}$ & $\begin{array}{l}-12.59 \\
(0.00)^{*}\end{array}$ & $\begin{array}{l}-0.78 \\
(0.82)\end{array}$ & $\begin{array}{l}-1.84 \\
(0.68)\end{array}$ & $\begin{array}{l}-12.79 \\
(0.00)^{*}\end{array}$ & $\begin{array}{l}-12.76 \\
(0.00)^{*}\end{array}$ \\
\hline NSE & $-0.77(0.82)$ & $\begin{array}{l}-1.91 \\
(0.64)\end{array}$ & $\begin{array}{c}-9.52 \\
(0.00)^{*}\end{array}$ & $\begin{array}{c}-9.50 \\
(0.00)^{*}\end{array}$ & $\begin{array}{l}-0.82 \\
(0.81)\end{array}$ & $\begin{array}{l}-1.92 \\
(0.64)\end{array}$ & $\begin{array}{l}-9.56 \\
(0.00)^{*}\end{array}$ & $\begin{array}{c}-9.53 \\
(0.00)^{*}\end{array}$ \\
\hline IIP & $0.56(0.98)$ & $\begin{array}{l}-2.08 \\
(0.54)\end{array}$ & $\begin{array}{l}-22.82 \\
(0.00)^{*}\end{array}$ & $\begin{array}{l}-22.81 \\
(0.00)^{*}\end{array}$ & $0.45(0.98)$ & $\begin{array}{l}-2.53 \\
(0.31)\end{array}$ & $\begin{array}{l}-22.82 \\
(0.00)^{*}\end{array}$ & $\begin{array}{l}-23.36 \\
(0.00)^{*}\end{array}$ \\
\hline
\end{tabular}

Table 1a: ADF and PP Test Results (Monthly data series)

Notes: The table reports the results of ADF and PP tests. The optimal lag for ADF test is selected based on the SIC criteria and for PP test for fixing the truncation lag, the spectral estimation method selected is Bartlett kernel and for Bandwidth is Newey-West method. In the case of both ADF and PP tests, the critical values at 1\% and 5\% are 3.43 , and -2.86 for the model without trend and -3.96 , and -3.41 for the model with trend respectively. Where $(*)$ and $(* *)$ denote significance level at $1 \%$ and $5 \%$, respectively. ADF and PP tests examine the null hypothesis of a unit root against the alternative of stationary and p-values are in parentheses.

Table 1b: KPSS Test Results

\begin{tabular}{|l|c|c|c|c|}
\hline \multirow{2}{*}{ Variables } & \multicolumn{3}{|c|}{ KPSS } \\
\cline { 2 - 5 } & \multicolumn{2}{|c|}{ Level } & \multicolumn{2}{c|}{$\mathbf{1}^{\text {st }}$ Difference } \\
\hline & Constant \& no Trend & Constant \& Trend & Constant \& no Trend & Constant \& Trend \\
\hline BSE & $1.129^{*}$ & $0.267^{*}$ & 0.134 & 0.115 \\
NSE & $1.188^{*}$ & $0.255^{*}$ & 0.117 & 0.107 \\
IIP & $1.492^{*}$ & $0.317^{*}$ & 0.177 & 0.104 \\
\hline
\end{tabular}

Note: The table presents KPSS test results. For fixing the truncation lag, spectral estimation method selected is the Bartlett kernel, and for bandwidth it is the Newey-West method. The critical values at $1 \%$ and $5 \%$ are 0.74 and 0.46 for the model without trend and 0.22 and 0.15 for the model with trend respectively. Where $(*)$ and $(* *)$ denote significance level at $1 \%$ and 5\% respectively. KPSS tests the null hypothesis of stationary against the alternative hypothesis of non- stationary. 
The table 1a and $1 \mathbf{b}$ illustrate the unit root tests statistics, comprising the ADF (Augmented Dickey and Fuller, 1979) and PP (Phillips and Perron, 1988) t-statistics and KPSS (Kwiatkowski et al., 1992) LM-statistic, the unit root tests are performed on the seasonally adjusted and natural logarithm data series. In case of ADF and PP tests the null hypothesis of a unit root (non-stationary) is tested against the alternative hypothesis no unit root (stationary). The unit root tests models are estimated at levels and first-difference for both with and without trend variable in each case. The estimated results of unit root tests show that for both with and without trend variable the ADF and PP t-statistics do not reject the null hypothesis of a unit root at the $5 \%$ level of significance or lower, for all the variables. This indicates that these series are non-stationary at their levels and therefore, that would confirm that those variables contain a unit root process. While applying the ADF and PP test statistics at first difference for each variable, then the null hypothesis of a unit root is rejected at $1 \%$ level of significance for both with and without trend. Further, KPSS test tests the null hypothesis of no unit root (stationary) against the alternative hypothesis of a unit root (non-stationary). The table 1b provides KPSS test statistics, where the null hypothesis of no unit root is rejected at $1 \%$ level of significance for all the variables with and without trend. This means KPSS test does not reject the null hypothesis of unit root at first difference for all the variables with and without trend.

Table 2a: ADF and PP Test Results (Quarterly data series)

\begin{tabular}{|c|c|c|c|c|c|c|c|c|}
\hline \multirow[b]{3}{*}{ Variables } & \multicolumn{4}{|c|}{ ADF } & \multicolumn{4}{|c|}{$\mathbf{P P}$} \\
\hline & \multicolumn{2}{|c|}{ Level } & \multicolumn{2}{|c|}{$\mathbf{1}^{\text {st }}$ Difference } & \multicolumn{2}{|c|}{ Level } & \multicolumn{2}{|c|}{$1^{\text {st }}$ Difference } \\
\hline & $\begin{array}{c}\text { Constant } \\
\text { \& no } \\
\text { Trend }\end{array}$ & $\begin{array}{l}\text { Constant } \\
\text { \& Trend }\end{array}$ & $\begin{array}{c}\text { Constant \& } \\
\text { no Trend }\end{array}$ & $\begin{array}{l}\text { Constant } \\
\text { \& Trend }\end{array}$ & $\begin{array}{c}\text { Constant \& } \\
\text { no Trend }\end{array}$ & $\begin{array}{l}\text { Constant } \\
\text { \& Trend }\end{array}$ & $\begin{array}{c}\text { Constant } \\
\text { \& no } \\
\text { Trend }\end{array}$ & $\begin{array}{l}\text { Constant } \\
\text { \& Trend }\end{array}$ \\
\hline BSE & $\begin{array}{l}-1.06 \\
(0.72)\end{array}$ & $\begin{array}{l}-2.02 \\
(0.57)\end{array}$ & $\begin{array}{c}-4.49 \\
(0.00)^{*}\end{array}$ & $\begin{array}{c}-4.44 \\
(0.00)^{*}\end{array}$ & $-0.88(0.79)$ & $\begin{array}{l}-1.83 \\
(0.67)\end{array}$ & $\begin{array}{c}-4.51 \\
(0.00)^{*}\end{array}$ & $\begin{array}{c}-4.46 \\
(0.00)^{*}\end{array}$ \\
\hline NSE & $\begin{array}{l}-1.12 \\
(0.69)\end{array}$ & $\begin{array}{l}-2.12 \\
(0.52)\end{array}$ & $\begin{array}{c}-4.63 \\
(0.00)^{*}\end{array}$ & $\begin{array}{c}-4.57 \\
(0.00)^{*}\end{array}$ & $-0.88(0.78)$ & $\begin{array}{l}-2.01 \\
(0.58)\end{array}$ & $\begin{array}{c}-4.65 \\
(0.00)^{*}\end{array}$ & $\begin{array}{c}-4.59 \\
(0.00)^{*}\end{array}$ \\
\hline GDP & $\begin{array}{c}1.52 \\
(0.99)\end{array}$ & $\begin{array}{l}-1.66 \\
(0.75)\end{array}$ & $\begin{array}{c}-8.10 \\
(0.00)^{*}\end{array}$ & $\begin{array}{c}-8.29 \\
(0.00)^{*}\end{array}$ & $1.52(0.99)$ & $\begin{array}{l}-1.58 \\
(0.78)\end{array}$ & $\begin{array}{c}-8.04 \\
(0.00)^{*}\end{array}$ & $\begin{array}{c}-8.29 \\
(0.00)^{*}\end{array}$ \\
\hline
\end{tabular}

Notes: The table reports the results of ADF and PP tests. The optimal lag for ADF test is selected based on the SIC criteria and for PP test for fixing the truncation lag, the spectral estimation method selected is Bartlett kernel and for Bandwidth is Newey-West method. In the case of both ADF and PP tests, the critical values at 1\% and 5\% are 3.43 , and -2.86 for the model without trend and -3.96 , and -3.41 for the model with trend respectively. Where $(*)$ and (**) denote significance level at $1 \%$ and $5 \%$, respectively. ADF and PP tests examine the null hypothesis of a unit root against the alternative of stationary and p-values are in parentheses.

Table 2b: KPSS Test Results

\begin{tabular}{|l|c|c|c|c|}
\hline \multirow{3}{*}{ Variables } & \multicolumn{3}{|c|}{ KPSS } \\
\cline { 2 - 5 } & \multicolumn{2}{|c|}{ Level } & \multicolumn{2}{c|}{$\mathbf{1}^{\text {st }}$ Difference } \\
\cline { 2 - 5 } & Constant \& no Trend & Constant \& Trend & Constant \& no Trend & Constant \& Trend \\
\hline BSE & $0.730^{* *}$ & $0.184^{* *}$ & 0.117 & 0.107 \\
NSE & $0.769^{*}$ & $0.178^{* *}$ & 0.108 & 0.100 \\
GDP & $0.962^{*}$ & $0.233^{*}$ & 0.431 & 0.053 \\
\hline
\end{tabular}

Note: The table presents KPSS test results. For fixing the truncation lag, spectral estimation method selected is the Bartlett kernel, and for bandwidth it is the Newey-West method. The critical values at $1 \%$ and $5 \%$ are 0.74 and 0.46 for the model without trend and 0.22 and 0.15 for the model with trend respectively. Where $(*)$ and $(* *)$ denote significance level at $1 \%$ and 5\% respectively. KPSS tests the null hypothesis of stationary against the alternative hypothesis of non- stationary.

The table 2a and $\mathbf{2 b}$ represents unit root tests results on quarterly data series; at levels ADF and PP tests do not reject the null hypothesis of unit root (non-stationary) for both with and without trend variable at $5 \%$ level of significance; and then at first difference the null hypothesis has been rejected at $1 \%$ level for both the models. It exposes that all the variables are non-stationary at their levels and mean reverting (stationary) at their first difference for both the models. In the case of KPSS 
test; the null hypothesis of no unit root (stationary) is rejected at levels for both the models at $5 \%$ or lower level of significance. On the other hand, the null hypothesis is not rejected at first difference for all the variables at $5 \%$ level. Given this observation study concludes that, the unit root tests results on both monthly and quarterly data series for all the variables are integrated order of one i.e., I (1) at their levels and follows stationary process at their first difference. This ensures that study can investigate long-run relationship among the studied variables by undertaking cointegration and error correction model.

\subsection{Granger Causality Test Results}

Table 3a: Granger Causality Test Results (Monthly data series with Stationary variables)

\begin{tabular}{|l|c|c|l|}
\hline Null Hypothesis & Number of Lags & F- Statistics (Probability) & Causal Relation \\
\hline BSE does not Granger Cause IIP & 2 & $2.54(0.08)^{* * *}$ & \multirow{2}{*}{ Bidirectional Relation } \\
IIP does not Granger Cause BSE & 2 & $3.65(0.03)^{* *}$ & \\
NSE does not Granger Cause IIP & 2 & $2.96(0.055)^{* * *}$ & \multirow{2}{*}{ Bidirectional Relation } \\
IIP does not Granger Cause NSE & 2 & $2.92(0.06)^{* * *}$ & \\
\hline
\end{tabular}

Where '**' and '***' indicate that the null hypothesis is rejected at $5 \%$ and $10 \%$ level of significance respectively.

Table 3b: Granger Causality Test Results (Quarterly data series with Stationary Variables)

\begin{tabular}{|l|c|c|l|}
\hline Null Hypothesis & Number of Lags & F- Statistics (Probability) & Causal Relation \\
\hline BSE does not Granger Cause GDP & 2 & $1.64(0.21)$ & No Relation \\
GDP does not Granger Cause BSE & 2 & $2.12(0.13)$ & Unidirectional Relation from \\
NSE does not Granger Cause GDP & 2 & $1.29(0.28)$ & GDP to S\&P CNX Nifty \\
GDP does not Granger Cause NSE & 2 & $2.74(0.07) * * *$ & \\
\hline
\end{tabular}

Where '***' indicates that the null hypothesis is rejected at $10 \%$ level of significance.

The table 3a and 3b signifies Granger causality test results on monthly and quarterly data series respectively. The estimations are carried out on the stationary variables and appropriate lag length is selected based on the Akaike Information Criterion (AIC). The causality test results on monthly series indicates that the null hypothesis of BSE does not Granger cause IIP is rejected at $10 \%$ level and the null hypothesis of IIP does not Granger cause BSE is also rejected at $5 \%$ level of significance. Similarly, the null hypothesis is also rejected in both directions for NSE and IIP at $10 \%$ significance level and then it is evidenced that there is a bidirectional relationship among the considered variables. Granger causality test results on monthly series indicate that causality runs in both directions from stock market performance (stock prices) to economic growth (IIP) and vice versa. Similarly, table 3b divulges causality test results on quarterly data series, where the null hypothesis is not rejected in either direction for BSE and GDP but in another case the hypothesis is rejected in one way direction i.e., GDP does not Granger causes NSE with $10 \%$ level of significance. Hence, the quarterly data results display that there is no causal relationship in between BSE and GDP but in case of GDP and NSE there is one way causal relationship, which runs from GDP to NSE and that confirms unidirectional relationship among them.

\subsection{Engle-Granger Cointegration Test Results}

Table 4a: Engle-Granger Cointegration test for BSE and IIP (on monthly series)

\begin{tabular}{|l|c|c|}
\hline \multicolumn{3}{|c|}{ Regression based Engle-Granger Cointegration Method $\left(\mathrm{bse}_{t}=\beta_{0}+\beta_{1}\right.$ iip $\left.t_{t}+u_{t}\right)$} \\
\hline Variables & Coefficients & t-test (probability values) \\
\hline Constant & -2.09 & $-4.46(0.00)^{*}$ \\
IIP & 2.05 & $22.85(0.00)^{*}$ \\
\hline
\end{tabular}

R-squared value 0.77 
Table 4a: Engle-Granger Cointegration test for BSE and IIP (on monthly series) - continued

\begin{tabular}{|l|c|}
\hline \multicolumn{2}{|c|}{ Residual based Regression Method $\left(\Delta z_{t}=\beta z_{t-1}+v_{t}\right)$} \\
\hline Variable & ADF-test (probability value) \\
Residual & $-2.38(0.02)^{*}$ \\
\hline
\end{tabular}

Where '*' implies that the rejection of null hypothesis at $5 \%$ or lower level of significance

Table 4b: Engle-Granger Cointegration test for NSE and IIP (on monthly series)

\begin{tabular}{|l|c|c|}
\hline \multicolumn{3}{|c|}{ Regression based Engle-Granger Cointegration Method $\left(n s e_{t}=\beta_{0}+\beta_{1}\right.$ iip $\left.p_{t}+u_{t}\right)$} \\
\hline Variables & Coefficients & t-test (probability values) \\
\hline Constant & -3.31 & $-8.00(0.00)^{*}$ \\
IIP & 2.05 & $26.00(0.00)^{*}$ \\
\hline
\end{tabular}

R-squared value 0.81

\begin{tabular}{|l|c|}
\hline \multicolumn{2}{|c|}{ Residual based Regression Method $\left(\Delta z_{t}=\beta z_{t-1}+v_{t}\right)$} \\
\hline Variable & ADF-test (probability value) \\
Residual & $-2.57(0.01)^{*}$ \\
\hline
\end{tabular}

Where '*' implies that the rejection of null hypothesis at $5 \%$ or lower level of significance

Table 5a: Engle-Granger Cointegration test for BSE and GDP (on quarterly series)

\begin{tabular}{|l|c|c|}
\hline \multicolumn{3}{|c|}{ Regression based Engle-Granger Cointegration Method $\left(b s e_{t}=\beta_{0}+\beta_{1} g d p_{t}+u_{t}\right)$} \\
\hline Variables & Coefficients & t-test (probability values) \\
\hline Constant & -15.35 & $-7.18(0.00)^{*}$ \\
GDP & 1.82 & $11.21(0.00)^{*}$ \\
\hline
\end{tabular}

R-squared value 0.72

\begin{tabular}{|l|c|}
\hline \multicolumn{2}{|c|}{ Residual based Regression Method $\left(\Delta z_{t}=\beta z_{t-1}+v_{t}\right)$} \\
\hline Variable & ADF-test (probability value) \\
Residual & $-2.93(0.04)^{*}$ \\
\hline
\end{tabular}

Where '*' implies that the rejection of null hypothesis at $5 \%$ or lower level of significance

Table 5b: Engle-Granger Cointegration test for NSE and GDP (on quarterly series)

\begin{tabular}{|l|c|c|}
\hline \multicolumn{3}{|c|}{ Regression based Engle-Granger Cointegration Method $\left(n s e_{t}=\beta_{0}+\beta_{1} g d p_{t}+u_{t}\right)$} \\
\hline Variables & Coefficients & t-test (probability values) \\
\hline Constant & -16.70 & $-8.65(0.00)^{*}$ \\
GDP & 1.83 & $12.50(0.00)^{*}$ \\
\hline
\end{tabular}

R-squared value 0.76

\begin{tabular}{|l|l|}
\hline \multicolumn{2}{|c|}{ Residual based Regression Method $\left(\Delta z_{t}=\beta z_{t-1}+v_{t}\right)$} \\
\hline Variable & ADF-test (probability value) \\
Residual & $-3.01(0.04)^{*}$ \\
\hline
\end{tabular}

Where '*' implies that the rejection of null hypothesis at $5 \%$ or lower level of significance

The table 4a and 4b presents Engle-Granger cointegration test results on monthly series. Where, study estimated regression based cointegration method by using non stationary data i.e., I (1) of BSE (or NSE) and IIP and then residual values are taken out and applied ADF test to see whether the series is stationary or not at levels. The residuals result of ADF test reject the null hypothesis of nonstationarity at $5 \%$ level of significance and provides evidence that there is a cointegration relationship between BSE and IIP in the long run. Similarly, study also estimated regression model of NSE and IIP, and found that there is also long run relationship. The table 5a and $\mathbf{5 b}$ unveils quarterly data results of Engel-Granger cointegration test. The study has estimated residual based cointegration method of BSE 
(or NSE) and GDP. The residual results of ADF test reject the null hypothesis of non stationarity at 5 $\%$ significance level. This suggests that there is a cointegration relationship between the considered variables in the study.

\subsection{Error Correction Model Results}

Table 6a: Error Correction Model for IIP and BSE (on monthly series)

\begin{tabular}{|c|c|c|}
\hline \multicolumn{3}{|c|}{ Regression based Error Correction Model $\left(\Delta_{\text {iip }}{ }_{t}=\alpha_{1} \Delta\right.$ iip $\left.t_{t-1}+\alpha_{2} \Delta_{b s e}+\alpha_{3} z_{t-1}+\varepsilon_{t}\right)$} \\
\hline Variables & Coefficients & t-test (probability values) \\
\hline$\Delta \mathrm{IIP}_{\mathrm{t}-1}$ & -0.54 & $-7.91(0.00)^{*}$ \\
\hline$\Delta \mathrm{BSE}_{\mathrm{t}}$ & 0.08 & $1.85(0.07)$ \\
\hline $\mathrm{Z}_{\mathrm{t}-1}$ & -0.04 & $-2.94(0.00)^{*}$ \\
\hline \multicolumn{3}{|c|}{ Regression based Error Correction Model $\left(\Delta\right.$ bse $e_{t}=\alpha_{1} \Delta$ bse $e_{t-1}+\alpha_{2} \Delta$ iip $\left.t+\alpha_{3} z_{t-1}+\varepsilon_{t}\right)$} \\
\hline$\Delta \mathrm{BSE}_{\mathrm{t}-1}$ & 0.04 & $0.44(0.66)$ \\
\hline$\Delta \mathrm{IIP}_{\mathrm{t}}$ & 0.11 & $0.84(0.40)$ \\
\hline $\mathrm{Z}_{\mathrm{t}-1}$ & 0.04 & $1.61(0.12)$ \\
\hline
\end{tabular}

Where, $\mathrm{Z}_{\mathrm{t}-1}$ is the residual values and ' $*$ ' implies that the rejection of null hypothesis at $1 \%$ level of significance

Table 6b: Error Correction Model for IIP and NSE (on monthly series)

\begin{tabular}{|c|c|c|}
\hline \multicolumn{3}{|c|}{ Regression based Error Correction Model ( $\left.\Delta i i p_{t}=\beta_{1} \Delta i i p_{t-1}+\beta_{2} \Delta n s e_{t}+\beta_{3} z_{t-1}+\varepsilon_{t}\right)$} \\
\hline Variables & Coefficients & t-test (probability values) \\
\hline$\Delta \mathrm{IIP}_{\mathrm{t}-1}$ & -0.54 & $-8.07(0.00)^{*}$ \\
\hline$\Delta \mathrm{NSE}_{\mathrm{t}}$ & 0.12 & $2.52(0.01)^{*}$ \\
\hline $\mathrm{Z}_{\mathrm{t}-1}$ & -0.05 & $-3.58(0.00)^{*}$ \\
\hline \multicolumn{3}{|c|}{ Regression based Error Correction Model $\left(\Delta n s e_{t}=\beta_{1} \Delta n s e_{t-1}+\beta_{2} \Delta i i p_{t}+\beta_{3} z_{t-1}+\varepsilon_{t}\right)$} \\
\hline$\Delta \mathrm{NSE}_{\mathrm{t}-1}$ & 0.26 & $3.25(0.00)^{*}$ \\
\hline$\Delta \mathrm{IIP}_{\mathrm{t}}$ & 0.16 & $1.53(0.12)$ \\
\hline $\mathrm{Z}_{\mathrm{t}-1}$ & 0.02 & $1.03(0.30)$ \\
\hline
\end{tabular}

Where, $\mathrm{Z}_{\mathrm{t}-1}$ is the residual values and ' $*$ ' implies that the rejection of null hypothesis at $5 \%$ or lower level of significance

Table 7a: Error Correction Model for GDP and BSE (on quarterly series)

\begin{tabular}{|l|c|c|}
\hline \multicolumn{3}{|c|}{ Regression based Error Correction Model $\left(\Delta g d p_{t}=\alpha_{1} \Delta g d p_{t-1}+\alpha_{2} \Delta b s e_{t}+\alpha_{3} z_{t-1}+\varepsilon_{t}\right)$} \\
\hline Variables & Coefficients & \multicolumn{1}{c|}{ t-test (probability values) } \\
\hline$\Delta \mathrm{GDP}_{\mathrm{t}-1}$ & -0.16 & $-1.09(0.28)$ \\
$\Delta \mathrm{BSE}_{\mathrm{t}}$ & 0.11 & $0.95(0.34)$ \\
$\mathrm{Z}_{\mathrm{t}-1}$ & -0.11 & $\mathbf{- 2 . 4 4}(\mathbf{0 . 0 2})^{*}$ \\
\hline \multicolumn{3}{|c|}{ Regression based Error Correction Model $\left(\Delta b s e_{t}=\alpha_{1} \Delta b s e_{t-1}+\alpha_{2} \Delta g d p_{t}+\alpha_{3} z_{t-1}+\varepsilon_{t}\right)$} \\
\hline$\Delta \mathrm{BSE}_{\mathrm{t}-1}$ & 0.29 & $2.01(0.05)$ \\
$\Delta \mathrm{GDP}_{\mathrm{t}}$ & 0.11 & $0.62(0.54)$ \\
$\mathrm{Z}_{\mathrm{t}-1}$ & 0.05 & $0.78(0.44)$ \\
\hline
\end{tabular}

Where, $\mathrm{Z}_{\mathrm{t}-1}$ is the residual values and '*' implies that the rejection of null hypothesis at $5 \%$ level of significance

Table 7b: Error Correction Model for GDP and NSE (on quarterly series)

\begin{tabular}{|l|c|c|}
\hline \multicolumn{4}{|c|}{ Regression based Error Correction Model $\left(\Delta g d p_{t}=\beta_{1} \Delta g d p_{t-1}+\beta_{2} \Delta n s e_{t}+\beta_{3} z_{t-1}+\varepsilon_{t}\right)$} \\
\hline Variables & Coefficients & t-test (probability values) \\
\hline$\Delta \mathrm{GDP}_{\mathrm{t}-1}$ & -0.19 & $-1.31(0.19)$ \\
$\Delta \mathrm{NSE}_{\mathrm{t}}$ & 0.13 & $1.19(0.24)$ \\
$\mathrm{Z}_{\mathrm{t}-1}$ & -0.15 & $\mathbf{- 2 . 9 0}(\mathbf{0 . 0 1})^{*}$ \\
\hline \multicolumn{4}{|c|}{ Regression based Error Correction Model $\left(\Delta n s e_{t}=\beta_{1} \Delta n s e_{t-1}+\beta_{2} \Delta g d p_{t}+\beta_{3} z_{t-1}+\varepsilon_{t}\right)$} \\
\hline$\Delta \mathrm{NSE}_{\mathrm{t}-1}$ & 0.24 & $1.62(0.11)$ \\
$\Delta \mathrm{GDP}_{\mathrm{t}}$ & 0.14 & $0.74(0.46)$ \\
$\mathrm{Z}_{\mathrm{t}-1}$ & 0.07 & $0.96(0.34)$ \\
\hline
\end{tabular}

Where, $\mathrm{Z}_{\mathrm{t}-1}$ is the residual values and '*' implies that the rejection of null hypothesis at $5 \%$ level of significance 
The monthly series results are presented in the table 6a and 6b. It confirms the Engle-Granger cointegration test that there is a long-run relationship between the studied variables in both monthly and quarterly series. We estimated error correction models by including the error correction term in the equations to see how the disequilibrium is corrected in the short-run. The results of monthly series reveal that when the IIP data is regressed on the BSE/NSE then the error correction term (-0.04/-0.05) is statistically significant at $1 \%$ level and when BSE/NSE is regressed on IIP then the error correction term is statistically insignificant. This implies that once the IIP and BSE (or NSE) deviates away from the long-run equilibrium, then the IIP makes all adjustment to reestablish the equilibrium by correcting disequilibrium about $4 \%$ (or $5 \%$ ) every month. Table 7a and $7 \mathbf{b}$ contains quarterly data results. The coefficients of the error correction terms (-0.11 and -0.15) in the GDP equations are statistically significant at $5 \%$ level. The error correction terms in the BSE and NSE equations are statistically insignificant. This implies that once the deviation takes from the long-run equilibrium between stock prices (BSE and NSE) and GDP, then the GDP initiates all adjustments to reestablish the equilibrium condition by correcting disequilibrium about $11 \%$ and $15 \%$ on each quarter in respective equations.

\section{Conclusion}

Our study investigated empirically the causal nexus between stock market performance and economic growth. This study also examined the short-run and long-run dynamics of the observed variables for the Indian context. The empirical analysis was carried out on monthly and quarterly series for the time span of April, 1996 to March, 2009. The results of ADF, PP and KPSS tests confirmed that the observed variables are integrated of order one i.e., I (1). This suggests the variables of the study are non-stationary (unit root) at their levels and then stationary at their first difference. The results of Granger causality test show that there is a bidirectional relationship between IIP and stock prices (BSE and NSE). This indicates that causality runs in both directions such as; from stock market performance (stock prices) to economic growth (IIP) and vice versa. Quarterly results of Granger causality test provide evidence that there is no causal relationship between BSE and GDP but in the case of NSE and GDP there is a unidirectional relationship and that runs from GDP to NSE.

Study also employed Engle-Granger cointegration test to investigate the long-run relationship between the observed variables. As it is evidenced from the unit root tests that all the variables are integrated with same order i.e. I (1). The study estimated regression based cointegration method on non-stationary data and applied ADF test on the generated residuals to see whether the series is stationary or not at levels. The residual results of ADF test has rejected the null hypothesis of nonstationarity at $5 \%$ significance level and conformed that there is a long-run relationship between the stock market performance and economic growth for both monthly and quarterly series. Error correction model was estimated to see how the disequilibrium is corrected in the short-run. The monthly results of error correction model signifies that once the IIP and BSE (or NSE) deviates away from the long-run equilibrium, then IIP makes all adjustment to restore the long-run equilibrium by correcting disequilibrium about $4 \%$ (or 5\%) on each month. Similarly, quarterly results of error correction model shows that in the short-run GDP initiates all alterations to reestablish the long-run equilibrium state by rectifying the disequilibrium about $11 \%$ and $15 \%$ in the case of BSE and NSE respectively on every quarter.

Results of this study provide evidence in favor of 'demand following' hypothesis for the Indian context in the short-run. Findings of the study suggest that the economic growth has been playing an important role in determining the stock price movements and economic growth also tends to be more likely to stimulate and promote stock market development by adopting appropriate reallocation of resources. To the best of our knowledge, this is the first study to undertake both the exchanges (BSE and NSE) and growth variables (GDP and IIP) to study the causal nexus, short-run and long-run dynamics by utilizing seasonally adjusted series of monthly and quarterly data. The main contribution of study is in identifying the role of economic growth in stock market development. 
Understanding of the causal direction between economic growth and stock market may assist investors in their estimates of the future movements of the stock markets. This is important for investors in making asset allocation decisions. This understanding is of significance for policy makers in developing policies to best suit economic objectives for the country.

\section{References}

[1] Abu-Bader, S. and Abu-Qarn, A.S., (2005) "Financial Development and Economic Growth: Time Series Evidence from Egypt” Discussion Paper No. 05-14, Monaster Center for Economic Research, Ben-Gurion University of the Negev, Israel.

[2] Acharya, D., Amanulla, S., and Joy, S., (2009) "Financial Development and Economic Growth in Indian States: An Examination" International Research Journal of Finance and Economics, ISSN 1450 Issue 24, pp. 117-130.

[3] Adajaski C.K.D. and Biekpe, N.B., (2006) "Stock Market Development and Economic Growth: The case of selected African countries" African Development Review 18(1) pp. 144-161.

[4] Agarwal, S., (2001) "Stock Market Development and Economic Growth: Preliminary Evidence from African Countries" (http://www.jsd-africa.com/Jsda/spring2001/articlespdf/ARC\%20\%20Stock\%20Market\%20Development\%20and\%20Economic\%20Growth.pdf)

[5] Agrawalla, R. K. and Tuteja, S. K., (2007) "Causality between Stock Market Development and Economic Growth: A Case Study of India” Journal of Management Research, 7, pp. 158-168.

[6] Alam, M. I., Hasan, T., (2003) "The Causality between Stock Market Development and Economic Growth: Evidence from the United States" Studies in Economics and Finance, 21 (1), pp. 93-104.

[7] Arestis, P., Demetriades, P. and Luintel, K., (2001) "Financial Development and Economic Growth: The Role of Stock Markets" Journal of Money, Credit, and Banking 33(1), pp. 16-41.

[8] Arrow, K.J., (1964) “The Role of Securities in the Optimal Allocation of Risk Bearing” Review of Economic Studies 2, pp. 91-96.

[9] Atje, R. and Jovanovic, B. (1993) "Stock Market Development” European Economic Review, 37, pp. 632-640.

[10] Barro, R. J., (1989) “The Stock Market and Investment" Working Paper No. 2925, National Bureau of Economic Research, 1050, Massachusetts Avenue, Cambridge, MA 02138.

[11] Bencivenga, V. and Smith, B., (1991) "Financial Intermediation and Endogenous Growth" Review of Economic Studies, pp. 195-209.

[12] Bhattacharya, P.C. and Sivasubramanian, M. N., (2003) "Financial Development and Economic Growth in India: 1970-1971 to 1998-1999” Applied Financial Economics, Vol. 13, pp. 925929.

[13] Brasoveanu, L. O., Dragota, V., Catarama, D. and Semenescu, A., (2008) "Correlations between Capital Market Development and Economic Growth: The Case of Romania" Journal of Applied Quantitative Methods, Vol.3, No.1, pp. 64-75.

[14] Caporale, G.M., Howells, P.G.A. and Soliman, A.M. (2004) "Stock Market Development and Economic Growth: The Causal Linkages" Journal of Economic Development, Vol. 29, No. 1, pp. 33-50.

[15] Chakraborty, I., (2008) "Does Financial Development Cause Economic Growth? The Case of India" South Asia Economic Journal, 9:1, pp. 109-139.

[16] Dailami M. and Atkin, M., (1990) "Stock Markets in Developing Countries: Key Issues and a Research Agenda" Policy, Research, and External Affairs Working Papers No. WPS 515, Country Economics Department, The World Bank Group.

[17] Deb, S. G. and Mukherjee, J., (2008) "Does Stock Market Development Cause Economic Growth? A Time Series Analysis for Indian Economy" International Research Journal of Finance and Economics, Issue 21, pp. 142-149.

[18] Debreu, G., (1959), “Theory of Value” New York: Wiley 
[19] Demetriades, P. and Hussein, K., (1996) "Does Financial Development Cause Economic Growth? Time Series Evidence from 16 Countries” Journal of Development Economics, 51, pp. 387-411.

[20] Demirguc-Kunt, A. and Levine, R., (1996) "Stock Markets, Corporate Finance and Economic Growth: An Overview" World Bank Economic Review, 10(2), pp. 223-39.

[21] Devereux, M. B. and Smith, G. W., (1994) "International Risk Sharing and Economic Growth" International Economic Review, 35(4), pp. 535-50.

[22] Dickey, D.A. and Fuller, W.A., (1979) "Distribution of the Estimators for Autoregressive Time Series with a Unit Root" Journal of the American Statistical Association, 74, pp. 427-431.

[23] El-Wassal, K. A., (2005) "Understanding the Growth in Emerging Stock Markets" Journal of Emerging Market Finance 4, pp. 227-261.

[24] Engel, R.E. and Granger, C.W.J. (1987), "Cointegration and Error Correction: Representation, Estimation and Testing” Econometrica, Vol. 55, pp. 251-76.

[25] Filer, Hanousek and Nauro (1999) “Do Stock Markets Promote Economic Growth?” Working Paper No. 267.

[26] Friedman, M. and Schwartz, A.J., (1963) “A Monetary History of the United States" Princeton University Press, Princeton Goldsmith, R.W., (1969) "Financial Structure and Development" Yale University Press, New Haven Granger, K.R., (1969) "Investigating Causal Relations by Econometric Models and Cross-Spectral Methods” Econometrica, 37, pp. 424-438.

[27] Gupta, R. and Donleavy, G. D., (2009) "Benefits of Diversifying Investments into Emerging Markets with Time-Varying Correlations: An Australian Perspective" Journal of Multinational Financial Management, 19, pp. 160-177.

[28] Jefferis, K. and Okeahalam, C., (2000) "The Impact of Economic Fundamentals on Stock Markets in Southern Africa. Dev. South. Afr., 17, pp. 23-51.

[29] Kamat, M. S. and Kamat, M. M., (2007) "Does Financial Growth Lead Economic Performance in India? Causality-Cointegration using Unrestricted Vector Error Correction Models" MPRA Paper No. 6154, pp. 1-26.

[30] King, R. G. and Levine, R., (1993a), "Finance and Growth: Schumpeter Might Be Right" Quarterly Journal of Economics, 108, pp. 717-738.

[31] King, R. G. and Levine, R., (1993b), "Finance, Entrepreneurship, and Growth: Theory and Evidence", Journal of Monetary Economics, 32, pp. 513-542.

[32] Korajczyk, R. A., (1996) “A Measure of Stock Market Integration for Developed and Emerging Markets" The World Bank Economic Review 10(2), pp. 267-89.

[33] Kuznets, S. (1955) "Economic Growth and Income Inequality" American Economic Review 45, pp. 1-28.

[34] Kwiatkowski, D., Phillips, P.C.B., Schmidt, P. and Shin, Y., (1992) "Testing the Null Hypothesis of Stationarity against the Alternative of a Unit Root: How sure are we that Economic Time Series have a Unit Root", Journal of Econometrics, Vol. 54, pp. 159-78.

[35] Levine, R. and Zervos, S., (1996) "Stock Market Development and Long-Run Growth" World Bank Economic Review, 10(2), pp. 323-39.

[36] Levine, R. and Zervos, S., (1998) "Stock Markets, Banks and Economic Growth" American Economic Review, 88(3), pp. 537-58.

[37] Luintel, K. and Khan, M., (1999) "A Quantitative Reassessment of the Finance-Growth Nexus: Evidence from a Multivariate VAR" Journal of Development Economics 60, pp. 381-405.

[38] MacKinnon, J.G., (1996) "Numerical Distribution Functions for Unit Root and Cointegration Tests" Journal of Applied Econometrics, 11, pp. 601-618.

[39] Mauro, P., (2000) "Stock Returns and Output Growth in Emerging and Advanced Economies" IMF Working Paper, No. 89.

[40] Morck, Randal, Shleifer, Andrei and Vishny, R.W., (1990a) "The Stock Market and Investment: Is the Market a Sideshow?" Brookings Papers on Economic Activity, 2, pp. 157215. 
[41] Mun, H.W., Siong, E.C. and Long, B.S., (2008) "Stock Market and Economic Growth in Malaysia: Causality Test. Asian Social Science, 4, pp. 86-92.

[42] Naceur, S.B., and Ghazouani, S., (2007) "Stock Markets, Banks, and Economic Growth: Empirical Evidence from the MENA Region” Research in International Business and Finance, 21, pp. 297-315.

[43] Nagaishi, M., (1999) "Stock Market Development and Economic Growth: Dubious Relationship" Economic and Political Weekly, Vol.34, No. 29, pp. 2004-2012.

[44] Ndikumana, L., (2001) "Financial Markets and Economic Development in Africa" Working Paper Series

[45] Obstfeld, M., (1994) "Risk-Taking Global Diversification and Growth" American Economic Review, 84, pp. 1310-1329.

[46] Odhiambo, N. M., (2008) "Stock Market Development and Economic Growth in South Africa: An ARDL-Bounds Testing Approach" (http://www.wbiconpro.com/2.Nicholas.pdf) Oskooe, S.A.P., (2010) "Emerging Stock Market Performance and Economic Growth" American Journal of Applied Science 7 (2), pp. 265-269.

[47] Padhan, P.C., (2007) "The Nexus between Stock Market and Economic Activity: An Empirical Analysis for India” International Journal of Social Economics, Vol. 34, No. 10, pp. 741-753.

[48] Pagano, M., (1993) "Financial Markets and Growth: An Overview" European Economic Review, 37, pp. 613-622.

[49] Patrick, H.T., (1966) "Financial Development and Economic Growth in Underdeveloped Countries" Economic Development and Cultural Change, 14 (2), pp. 174-187.

[50] Pearce, D.K., (1983) "Stock Prices and the Economy," Federal Reserve Bank of Kansas City Economic Review, pp. 7-22.

[51] Phillips, P.C.B. and Perron, P., (1988) "Testing for a Unit Root in Time Series Regression" Biometrika, Vol. 75, pp. 335-46.

[52] Ram, R., (1999) "Financial Development and Economic Growth: Additional Evidence" The Journal of Development Studies 35, pp. 164-174.

[53] Robinson, J., (1952) "The Rate of Interest and Other Essays" Macmillan, London Schumpeter, J. A., (1911) "The Theory of Economic Development" Cambridge MA7, Harvard University Press Shirai, S., (2004) "Testing the Three Roles of Equity Markets in Developing Countries: The case of China. World Development 32, pp. 1467-1486.

[54] Shleifer, A. and Summers, L., (1988) "Breach of Trust in Hostile Takeovers" in A. Auerbach, ed., Corporate Takeovers: Causes and Consequences, Chicago, University of Chicago Press, 33-56.

[55] Sinha, D. and Macri, J. (2001) "Financial Development and Economic Growth: The case of Eight Asian Countries, Economia-Internazionale, 54 (2), pp. 219-34.

[56] Vazakidis, A. and Adamopoulos, A., (2009) "Stock Market Development and Economic Growth” American Journal of Applied Science 6 (11), pp. 1933-1941. 